\title{
Chapter Five: \\ Representing the State, Molding the Nation
}

\section{Folk Dress and Representative Attire}

Israel's national airline El-Al was founded in 1949. Six years later, an "Air Queen" international competition was held in Johannesburg, South Africa, to elect the most professional and pleasant air hostess. The El-Al hostess who represented Israel in the contest won the second place. Like national beauty queens who represented the state in international beauty competitions, so did flight attendants embody the young state both internally and externally. They too were physically attractive women. ${ }^{1}$

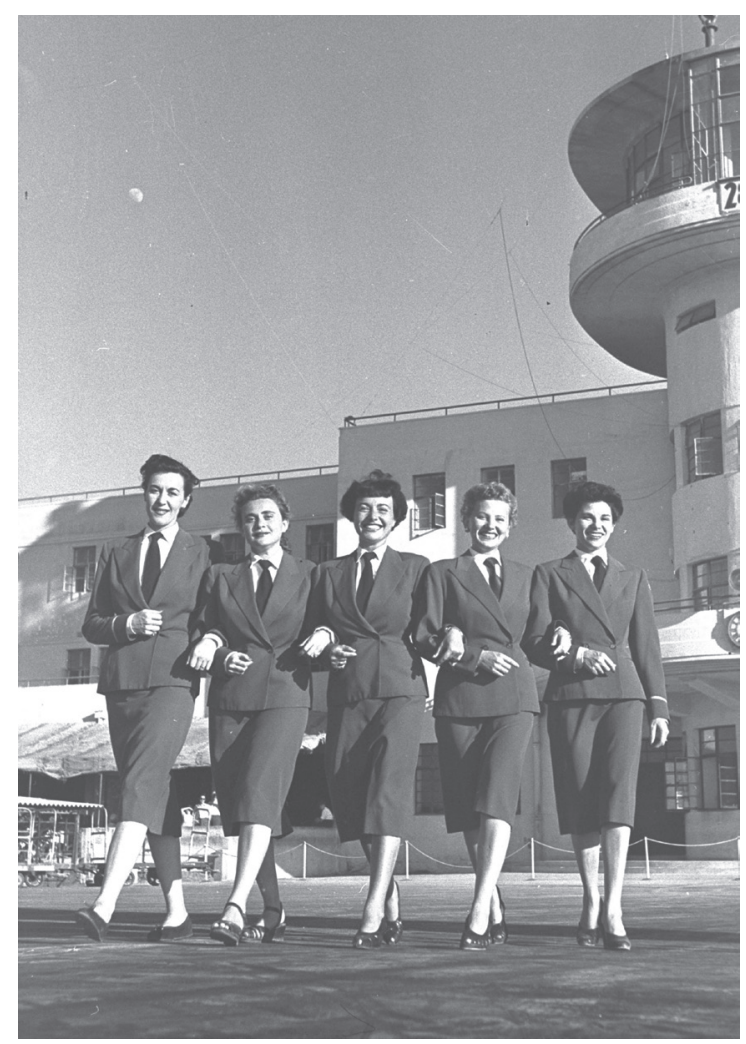

Figure 5.1: Ground hostesses from the government tourist department at the Israeli National Airport in 1952.

Government Press Office, NPC, D391-079. Photo by Teddy Brauner. 
The airport- the first Israeli site to be viewed by tourists-was regarded as the state's "display window," and therefore its workers were to make a good impression and look "representative." In spite of their formal appearance, including a masculine tie, the hostesses' uniforms looked smart and fashionable, and complimented the female body with their fitted skirts, narrow waists, and feminine shoes. In Israel, a young state extremely sensitive about its image and reputation, El-Al uniforms were created by Lola Ber and other leading fashion designers. ${ }^{3}$ These uniforms were expected and intended to play a formal national role. ${ }^{4}$

Ideas of molding a Zionist national dress first emerged during the Yishuv era. In 1923, for instance, a reader's letter published in a socialist women's magazine suggested that local artists create a national dress to be shared by all classes. Rather than imitating Western dress blindly, those who settle in the East should fit their dress to the country's climate and "spirit." In 1939 a reader wrote to another magazine about the national importance of dress, calling on the Zionist institutions to set a committee to determine a unified style of dress. Three years earlier, in the Levant Fair held in Tel Aviv, a contest was announced for designing an original Hebrew dress, "combining Eastern and Western cultures, symbolizing the revival of the Hebrew heritage in the Land of Israel." The two winning dresses were both creations of a leading local designer, Pnina Riva: a casual dress in the shape of a Ukrainian sarafan, titled "Daughter of my people," and an evening gown in the shape of an Arab abaya, titled "Daughter of Zion." These winning dresses were not adopted by the women of the Yishuv as their daily or ceremonial dresses. Yet Raz mentions that after the foundation of the state, Riva's 1936 winning evening gown was worn by the first Israeli beauty queen when she represented the state in the international beauty contest. ${ }^{5}$

Indeed, the issue of a national dress was raised again after the state was founded. In May 1955 a group of painters, directors, actors, and other professionals was gathered in Jerusalem to discuss the issue of styling a national folk dress. Some of the participants proposed imitating the colorful Arab embroidery, others suggested adopting the Yemenite tunic, others still advocated drawing inspiration from Israeli landscape and from Jewish historical sources or using the experience already gathered by local scenery painters, directors of public ceremonies, and dance companies. One participant proposed gathering women's dresses from all Jewish Diasporas, exhibiting them to the public, 
and holding a referendum among Israelis and Jews abroad in order to elect the favorite dress as the national folk attire. Two artists propounded announcing a public bid for the design of a national dress, and two directors suggested conducting an ethnic fashion show as a basis for a future ethnographic museum. One participant claimed that ethnic Jewish dress should be gathered before it disappears, although this, she added, cannot solve the problem since "a sartorial style cannot be created artificially" but rather evolves gradually from a place's climate and its peoples' lives. The meeting, which focused on women's dress in particular and did not mention men's wear at all, ended without reaching any practical decision. ${ }^{6}$ The speakers did not distinguish between folk and national dress, and it seems that the target of the consultation was never clearly delineated: was it about ethnographic research of traditional Jewish dress, the creation of a representative outfit for dance and theater performances, or the design of an obligatory national outfit for ceremonial use?

Other discussions of the topic reveal similar ambiguity and no clear distinctions between folk dress, national dress, and fashion. Thus a 1952 letter published in Dvar hapo'elet claimed that Israel still lacks a national dress because

Folk style does not emerge according to a set plan, [but rather] is the result of mass effort. An original national dress is a collective creation of tens of thousands of women, mothers and girls, accumulating the tendencies, the experiences and the tastes of generations.

Such an effort does not exist in Israel, the writer lamented, where instead of nurturing a unique national style, women keep imitating foreign tastes and patterns. ${ }^{7}$

For the sake of analytical clarity, let us distinguish between folk and national dress. The former develops within local communities over ages, and is part of their rooted customs and values. Folk dress is supervised by the community; it separates it from other communities and internally classifies and grades its members. National dress, on the other hand, is associated with residency or citizenship in a state, and as such might envelope a population of various ethnic groups and communities, each having a different folk dress. Whereas folk dress is molded 
gradually on the grassroots level, national dress is defined and nurtured by state authorities and agencies. National dress can either utilize elements from existing folk traditions or intentionally replace the local folk dress. Sometimes newly invented national dress is promoted as having ancient folk roots. Both folk dress and national dress are non-fashion forms of clothing: whereas fashion is cosmopolitan and ever-changing, folk and national dress are local and tend toward stability. ${ }^{8}$

Although not all national dress is necessarily based on folk dress, many modern national movements search for the people's historical roots, and therefore designers of national dress might choose a certain traditional dress, announce that it epitomizes the "spirit" of the people, adopt it, and combine its features into the new national dress. ${ }^{9}$ Thus Riva's choice of the Ukrainian sarafan and the Arab abaya for her 1936 national designs were echoed after the foundation of the state: the sarafan, as well as the embroidered Russian rubashka, were worn within the austere style of dress, particularly in the kibbutzim and by members of youth movements, and Israeli fashion designers sometimes used the abaya shape for their models. ${ }^{10}$ As we saw, during the 1950 s the sartorial traditions of new immigrants from Muslim countries, the Yemenites in particular, became the main source of inspiration for designers who tried to infuse a "local" character into their creation.

A unique Israeli costume was gradually consolidated in the field of "folk dancing." Since the Yishuv era, local dances-to be practiced by the wide population and not necessarily by trained or professional dancers-were being invented by several choreographers. Danced to Hebrew songs and combining steps from different Jewish Diasporas as well as local Arab dances, these new "folk dances" were regarded as an authentic national creation, expressing Zionist and pioneering ideals and depicting national notions about the land. Beginning in 1944, national dance conventions were held in one of the kibbutzim, and since 1953 dancing parades were performed during some of the national holidays. Israeli folk dances are an example of a modern invented tradition, initially begun by groups of settlers but from the 1940s run and distributed by national institutions, which trained dance teachers and tried to spread new folk dances among the population. In addition to their internal role of acculturating Israelis into "worthy" national ideals, Israeli folk dances quickly became an attraction for tourists and a representative Israeli performance abroad. ${ }^{11}$ 
While ballroom dances were identified with foreign influences and indeed conducted in fashionable Western evening wear, Israeli folk dances, associated with national authenticity, required a unique costume. Some dances were performed in costumes according to their ethnic, geographic, or thematic inspirations (for instance Hassidic, Yemenite, or pseudo-Biblical costumes), but a specific costume was molded for the majority of the dances, whose themes were Zionist or pastoral. Before the third folk-dancing convention in 1951, the organizing committee published a competitive bid and the winning costume was worn, in six color variations, by all performers. The costume included pants and a short tunic for the men, a skirt and a blouse for the women, and kerchiefs tied around the waist or the shoulders. The color combinations were bright (for instance black and white, blue and orange) and decorated with embroidered stripes. ${ }^{12}$

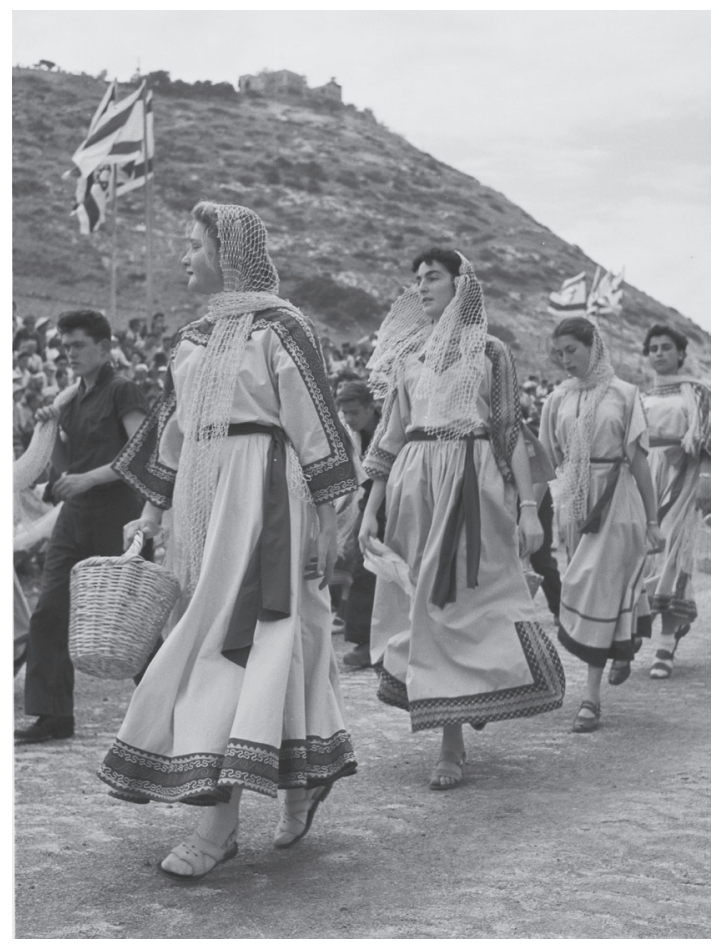

Figure 5.2: "The fishermen dance" in a dancing parade performed during Independence Day celebrations in Haifa, 1956.

Government Press Office, NPC, D726-095. Photo by Fritz Cohen. 
This outfit became the paradigm for Israeli folk-dancing costumes, and was seen in different variations in dance performances in kibbutzim and other settlements. Dresses with wide skirts for women, short loose tunics above long pants for men, decorations of embroidered stripes, bare feet and uncovered heads-this dance costume was eventually regarded as the quintessential Israeli "folk dress." ${ }^{13}$

Apart from a few brief exceptions, the folk costume was used solely for dance performances, but then again, this was the usual fate of folk dress in the modern era. Whether created gradually, along centuries, within traditional communities, or invented during a short while by designers, as in the Israeli case, in modern industrial societies folk dress is allocated to the limited sphere of performance and tourism. ${ }^{14}$ Yet sociologist Dina Roginsky shows how Israeli folk dances contain primary elements of folklore alongside elements of government patronage and commercialization. ${ }^{15}$ The institutionalization and commercialization of folk dancing and costumes does not necessarily testify to, or entail, decreased authenticity or reduced power as a national symbol. Local costumes can maintain and enhance the community's internal values even when they are performed in "exotic" versions for tourists. ${ }^{16}$

Israel had no set, formal and required national dress. ${ }^{17}$ Yet the leaders of the young state were very sensitive about its international reputation and about the impression it made on outsiders. Surrounded as it was by hostile Arab states and suffering from a sensitive international status, diplomacy and diplomats held an important place in Israel's first years of existence. The state sent ambassadors and consuls, delegates and envoys, military attachés and commercial advisors, according to its relationships with various states. Every foreign embassy or consulate that was opened in Israel was celebrated as a crucial occasion, and every diplomatic event was covered by the local media. Within the poor and informal Israeli society, foreign diplomats were regarded as the height of grandeur and formality, and the annual diplomats' ball was considered the most fashionable local event. ${ }^{18}$ 


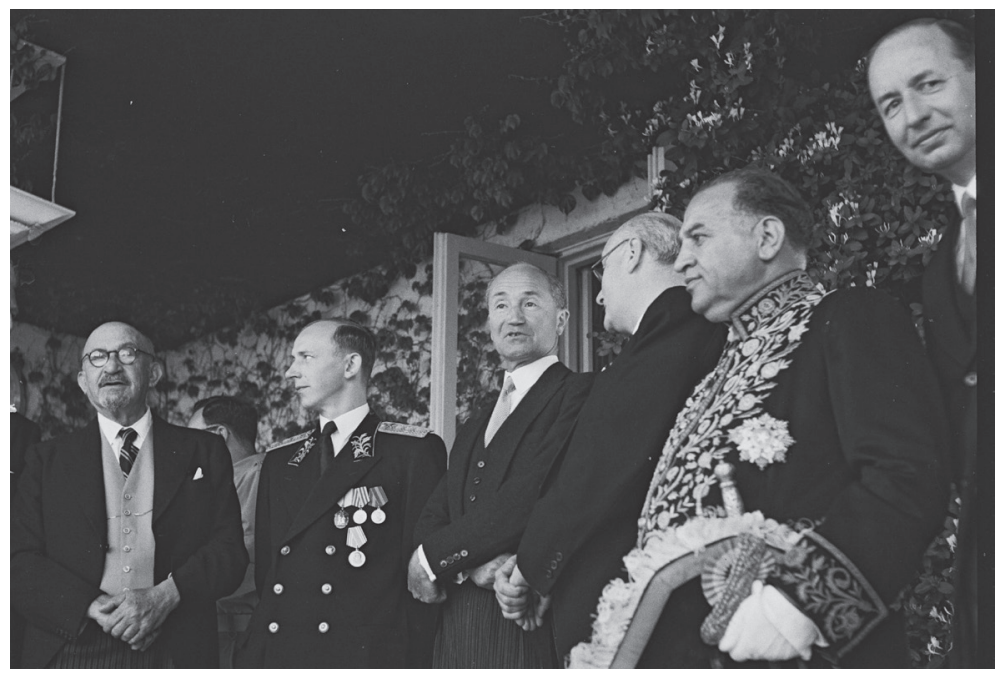

Figure 5.3: First Israeli president, Chaim Weizmann (left), receiving members of the diplomatic corps, 1950.

Government Press Office, NPC, D725-094. Photo by Hans Pinn.

But when it came to Israeli envoys abroad, the attitude to grand dress was more ambivalent. On the one hand, if Israel was to become a state like any other state, its envoys were supposed to dress according to diplomatic protocol and conventions. On the other hand, these norms contradicted the post-war poverty of the young state. According to hegemonic ideology, the country's leaders-members of parliament, cabinet ministers, high military officers, and their spouses and families-were supposed and expected to live and dress as befits the austere "spirit of the land." During the rationing regime, state representatives who bought extravagant clothes when they were abroad and then "flaunted" them in Israel, were publicly criticized. ${ }^{19}$

Then again, it was conceived as a national interest, rather than a private one, to dress Israelis who represented the state overseas in a suitable manner. Even during the height of the recession, members of the Israel Philharmonic Orchestra were dressed as properly as possible during their international tours. ${ }^{20}$ Sport delegations too were regarded as envoys of the state. In the popular imagination, a national team can take on the guise of the nation itself, symbolizing unity and strength. Nations are enshrined in sports via flags, anthems, and the national colors of a team's uniform. ${ }^{21}$ Thus, although sport wasn't exactly Is- 
rael's strongest field, international sporting events were deemed symbolically important even if they were professionally and aesthetically disappointing. ${ }^{22}$

Following the poor performance of the Israeli team at the Olympic Games in Helsinki in 1952, Prime Minister Ben-Gurion established a special committee to investigate the delegation's conduct. Finding no proof of misconduct, the committee nevertheless found some faults with the project's organization. ${ }^{23}$ It is interesting to note that one of the issues investigated by the committee was the delegation's representative outfit. One of the witnesses testified that all the members of the delegation, sportsmen as well as trainers and escorts, constantly wore the formal dress with the newly designed emblem of the state-a blue shield with the seven-branched menorah surrounded by two olive branches. ${ }^{24}$ Another witness, however, provided contrasting evidence and claimed that the outfit was not worn by all members on all formal occasions. He also argued that the Israeli sport outfit did not look imposing, certainly when compared with those of some of the other delegations, and that it made a poor impression on foreign participants and spectators. ${ }^{25}$ Clearly some importance was attributed to sartorial representation in Israel's first participation as a sovereign state on the Olympic stage.

The centralist state was involved in all aspects of formal national representation, and its institutions participated in molding and promoting formal culture, including folk dancing. But when it came to fashion the state did not interfere directly. It was mainly the local press and fashion journalists who encouraged designers to create a distinctive Israeli style by inserting unique elements into fashion. Local fashion designers were required not only to adjust international fashion to the local climate and the limiting economic conditions, but also to infuse into their models some "national character." In 1950 the fashion reporter of a feminist magazine suggested that rather than sending envoys to Paris, Israeli designers should create a style as appealing as Parisian style:

Instead of imitating everything imported, even the most grotesque models, wouldn't it be better to use a bit of imagination and good will and create a local fashion that beautifies everyone, fit even for the most snobbish women, those who believe that a dress from Paris could cover ugliness and lack of taste? 
She claimed that with the proper promotion, Israeli fashion could be exported to all the countries that share Israel's hot climate and ended with an overstated vision that "soon enough fashion from Tel Aviv will be in demand as much as fashion from Paris." ${ }^{26}$ The writer praised American fashion, which managed to break free from the dictates of Paris and assert its own character, but did not provide any concrete aesthetic suggestions of how to implement a similar break in the Israeli case. ${ }^{27}$

Reports on local fashion shows occasionally included some disappointed comments when the shows presented no recognizable "Israeli style," nothing "originally Israeli" alongside cosmopolitan trends. Fashion reporters lamented the fact that local fashion had not developed its unique look. The press and other factors expected a uniquely Israeli fashion to be created intentionally, perhaps with the help of a national committee or a national mind trust. ${ }^{28}$

Lola Ber, however, did not share this vision of a unique Israeli style. When asked "Do we have an original fashion of our own in Israel?," she replied unapologetically in the negative: only Paris creates an original fashion. Fashion, she claimed, requires a special atmosphere and a certain tradition, and therefore Paris' strong status in fashion will abide forever. Israel, said Ber, is a small country with limited possibilities in the field of fashion, but Israeli women can adopt and adjust Parisian fashion quickly and with much aptitude. ${ }^{29}$ Ber viewed fashion as an international phenomenon, based on one fashion center only, and her ambitious goal was to achieve aesthetic excellence locally by imitating the Parisian example successfully.

Ber said that it would take at least five hundred years to develop a unique Israeli fashion, but others wished to hurry the process. The easiest and most superficial way of "nationalizing" fashion was simply by giving models a local title. Thus names such as "Negev colored suit" or "Eilat beach" were bestowed on specific fashion models. The settlement of the Negev, the thinly populated desert in the south of Israel, was one of the young state's major projects, eagerly promoted by Prime Minister Ben-Gurion. Built at the south end of the Negev on the shore of the red sea, the young city of Eilat symbolized the new pioneering settlement. Therefore, naming fashion items after the Negev and Eilat were clear patriotic gestures. In 1955 an elegant fur hat was named by its local designer after the national airline "El-Al," and a top hair stylist from Tel 
Aviv named two of her ladies' haircuts after the Negev and another region in Israel, the Sharon. A more material way of nationalizing fashion was by using locally produced fabrics in the manufacture of high fashion. This was made possible when the quality of local textiles improved beginning in $1954 .^{30}$

Yet such technical forms of nationalizing fashion did not necessarily entail any stylistic innovation or singularity. This, as we recall, was usually provided by the integration of Eastern elements, but apart from Maskit's exceptional success, most Israeli designers found it difficult to furnish their models with an Israeli "national character." Other historical cases and precedents confirm that nationalizing fashion is no easy task and usually doomed to failure, because it involves separation and permanence that counter fashion's internationalism and its ceaseless motion. Whereas national dress is aimed at, and dictated by, political factors, fashion is an aesthetic mechanism; most of its changes are internal, autonomous, and led by arbiter elegantiae, whose prestige hardly depends on political issues. ${ }^{31}$

When Pnina Riva's latest designs were presented successfully in the United States in 1950, a local reporter wondered "and why shouldn't Tel Aviv too hold a central place in the production of luxurious eveningdresses in world markets?"32 Dress was supposed to contribute to the formation of the new Israeli national identity, but fashion was also inadvertently enhancing the centrality of Tel Aviv compared with Jerusalem's marginality. Historians have discussed the political risks and implications of defying the UN resolutions and announcing west Jerusalem as Israel's capital in $1949,{ }^{33}$ but transferring the government ministries from Tel Aviv to Jerusalem also involved some internal mundane dilemmas. Its symbolic significance for Zionism notwithstanding, wardevastated Jerusalem was a poorer, colder, less developed and less lively city than its coastal rival. It is no wonder that some government officials and clerks, as well as their wives, were reluctant about "leaving swanky Tel Aviv and settling in gloomy, dull, historical Jerusalem." ${ }^{34}$

Government workers who moved from the warm coastal plain to the colder mountain region had to be supplied with warmer winter apparel. ${ }^{35}$ But the regional differences between Tel Aviv and Jerusalem were not merely climatic: the former was associated with high fashion and the latest cosmopolitan trends, whereas the latter was considered traditional, conservative, and provincial. Tel Aviv had become the country's 
fashion center during the Yishuv era, and it maintained its position as the hub of fashion design, industry, and commerce after the foundation of the state. ${ }^{36}$ The identification of Tel Aviv with fashion was taken for granted, so much so that a reporter describing a fashion show in 1949 Tel Aviv wrote of the local urban audience as "the women of the capital." ${ }^{37}$ Referring to Tel Aviv, rather than to Jerusalem, as "the capital" was a significant slip of the pen: while formal national interest was set on turning Jerusalem into Israel's capital, in the flow of daily life, including the sphere of dress, Tel Aviv was often perceived as the country's actual cultural center. ${ }^{38}$

Even though Israeli fashion-like most other fashions-was rarely infused with a distinct "national" character, it is noteworthy that during the first years of statehood it was demanded that fashion designers express some national identity in their designs. The dress of envoys of all sorts was supposed to represent the sovereign state, and the costume of folk dancers was believed to embody the spirit of the ingathered nation in its old-new homeland. But there was one specific category of dress that symbolized poignantly both the new sovereignty of the Israeli state and the national revival of its people: the military uniform.

\section{"A People in Uniform"}

Israel was founded during a total war, and when the war ended, the cease-fire agreements did not bring about peace. Sociologists Horowitz and Lissak write that since its earliest days as an independent state, Israel had to prepare itself conceptually as well as strategically to withstand a continuous violent conflict. They define the Israeli experience as a "Nation in Arms" (or in the Hebrew version: "A People in Uniform"), because there are many meeting points between the civilian and the military, on both the private and the public levels. A recent study argues that Israel's security network stems from the particular power structure established by the founding fathers of the state, who sought to use the IDF to promote the processes of state formation and social integration. Thus the boundaries between the state's security and civilian spheres were deliberately kept porous. ${ }^{39}$ The War of Independence placed security and the army at Israel's political and social center. Army service during the war was a basic element in the educational myth toward national identity and unity. The IDF, its commanders, and its soldiers were placed 
at the focus of the national centralist idealism, over and above ideological, political, and partisan disagreements. ${ }^{40}$

The IDF was established in 1948, and during the war 100,000 soldiers were eventually mobilized. When the war ended, it was clear that Israel could not maintain such a large army, and a reserve system was designed, combining the regular army, the reserve army, and a smaller framework of professional soldiers. ${ }^{41}$ Prime Minister and Minister of Defense David Ben-Gurion regarded the IDF as a central unifying force in the young state. He viewed the IDF role as extending military matters, and as a nonpolitical "people's army" it was given leading missions of settlement and education. The IDF was involved in founding, populating, and defending new frontier settlements, and in helping to absorb the new immigrants in transit camps. These wider national missions enhanced the IDF status within Israeli society. At the same time, within the IDF, military service became a main tool for achieving the melting-pot goal as it forged "New Israelis" according to the centralist ideal. Different segments of Israeli society met during their army service. The IDF was a cardinal means of acculturating young new immigrants, teaching them Hebrew, and making many of them feel integrated into Israeli society. ${ }^{42}$

Military historian Mordechai Bar-On describes a comprehensive public support of the army in 1950s Israel, when military efficiency was regarded as a paramount interest of the state. Israel was put under siege by all its surrounding neighbors and attacked by infiltrators on a regular basis. Most Israelis conceived this situation as justifying the use of force and acknowledged the crucial importance of a strong army. Attempts were made to maintain the army's unity and prestige, to consolidate the soldiers' identification with the army's goals, and to nurture the civilians' fondness of the army. ${ }^{43}$

Involved in many non-military missions throughout the country, army soldiers were not a rare sight, restricted to army camps and training grounds, but rather a frequent recognizable feature in Israeli towns, kibbutzim, and transit camps. Many soldiers wore their service uniforms on leave as well as on duty. Their well-loved image constantly appeared on posters, illustrations, and even in commercial ads. ${ }^{44} \mathrm{~A}$ military pamphlet reminded IDF soldiers that outside the camp they are seen by citizens as the representatives of the army; in order to maintain and enhance the public respect and fondness of the army, soldiers were therefore instructed to keep a neat appearance, in addition to behaving 
politely. ${ }^{45}$ In late 1949 a journalist described some army vehicles, loaded with IDF soldiers, driving through a town:

What power lies in the faces of these young men, with their unruly forelocks! What graceful flexibility in their exposed and firm limbs! What confidence shines in their laughing eyes!

The writer then hears some old men talking about the soldiers, and saying that they differ from soldiers elsewhere in the world: most soldiers have a touch of evil, say these old men, whereas "our soldiers have a touch of Jewish sanctity." ${ }^{46}$ It is noteworthy and indicative of its special structure and status that the IDF was not just respected and admired among the Israeli public, but also liked. It inspired fondness, even love, rather than a distant awe. The army also presented itself to civilians in many public ceremonies, most famously in its annual military parade on Independence Day. ${ }^{47}$

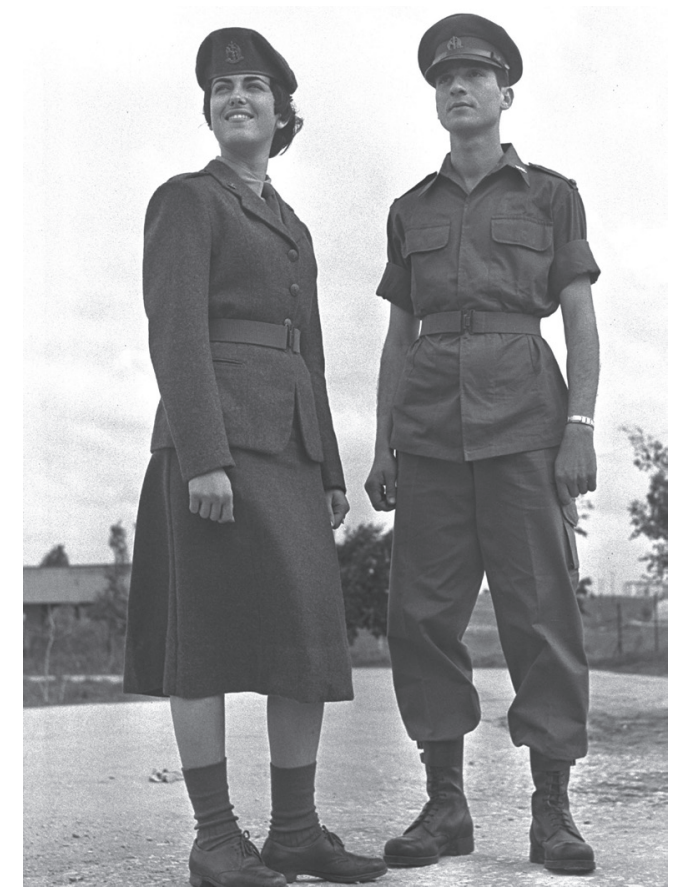

Figure 5.4: New military uniforms, 1956.

Government Press Office, NPC, D369-018. 
Many studies on the IDF and on Israel's military history have been published, but to date no research has focused on uniforms. The Hebrew word for "uniforms" is often used to designate military service in general, and the Hebrew expression "A People in Uniform" is frequently employed as a metaphor for the entire Israeli society, where the civilian and the military tend to overlap and merge. ${ }^{48}$ Let us therefore literalize the metaphor, and examine Israeli military uniforms in light of this dress' cardinal features: denoting legitimate use of power, symbolizing state authority, molding discipline, and representing manliness.

Unlike most kinds of modern dress, which are influenced by informal codes and social conventions, uniforms are a formal dress, dictated explicitly by institutions such as the army or the police force. The communicative power of military uniforms is much more precise than the limited, vague, and ambiguous codes of other kinds of clothes. Uniforms become direct denotative signs, socially familiar and wellknown, and therefore their "reading" does not depend on personal interpretation. Uniforms enhance the political goal of the modern army by symbolizing the legitimate use of force, and are therefore meant to be recognized and categorized at first sight. ${ }^{49}$

The IDF started issuing uniforms for its soldiers in late May 1948. About two-thirds of the uniforms were purchased and ordered in Israel. Ata, the large textile manufacturer, was one of its main suppliers. About one-third of the IDF uniforms were ordered from abroad, in particular from the United States. Many of the purchased items were second-hand. An alternative source was gifts and donations, most of them sent by American Jews. During the war supply was often detained and slow, but first to receive any available uniforms were soldiers serving in the front lines. An acute shortage in army shoes was later solved by import from Australia. When the battles were over, more attention could be paid to the uniform, but the IDF Quartermaster's department met with numerous material and technical problems. In late 1949 a special military committee, peopled by representatives from all the main corps, was founded in order to deal with all matters of uniforms and insignia. ${ }^{50}$

Until early 1950 uniforms were not purchased according to any set plan, but rather at different available opportunities and from all over the world. Now, when the war was over, it was decided to set a plan and 
to use the full capacity of local manufacturers for the army's needs. ${ }^{51}$ The implementation of the plan, however, was restricted by the economic crisis of the time and affected by shortage of raw materials, lack of foreign currency for importing materials and items from abroad, and the deteriorating quality of local textile products. During 1950 the IDF tried to finalize the shape of both battle dress and service uniforms for its different forces and units, but the rationing of clothes and shoes, introduced that same summer, piled new difficulties on the realization of these plans. ${ }^{52}$

Sometimes different practical considerations - comfort, health, and cost-clashed and contradicted each other. In early 1950, for instance, the IDF debated the issue of short pants, a popular Israeli item of clothing that was often worn by soldiers during the war. Some factors in the supply flank claimed that shorts should not be used any longer in the army, because they were wasteful: they could only be worn in daytime and for order drills, but not for training or during nighttime. The commanders of the forces and the Chief of Staff disagreed, claiming that soldiers should be allowed to wear shorts in Israel's steaming hot summertime. The military medical officer supported the latter and wrote that shorts are used by all armies in tropical and sub-tropical climates; they allow the soldiers freer movement and reduce their amount of sweating; they are cheaper than longer pants and are less prone to be damaged by washing. ${ }^{53} \mathrm{~A}$ few years later the IDF stopped issuing short pants as part of its uniforms, but during the first years of the state this item was so central and ingrained in the existent Israeli sartorial culture that it seemed inconceivable to do without it in the army.

Alongside practical considerations, such as cost, climate, and health, historical documents reveal that military factors were also concerned with aesthetic considerations. Since 1949 the army had dealt with different types of uniforms: battle dress uniforms for actual combat and training, service uniforms for military ceremonies and for non-combat activities, and formal uniforms, issued only for soldiers and officers who represented the army overseas. The difference between battle dress and service uniforms can be clearly seen in the case of the navy: work on board was performed with dark khaki tattered uniforms (some soldiers worked with no shirts on), whereas in formal ceremonies the soldiers wore their gleaming white uniforms. ${ }^{54}$

IDF summer uniforms were made of bright khaki cotton while win- 
ter uniforms were cut in the British battle-dress shape and made of dark khaki wool. When the Quartermaster's department announced that it could not provide belts for all the units, and therefore suggested discarding this item from the uniforms altogether, a question arose whether the belt was an integral part of a military uniform, and whether a soldier could look neat enough without it. Eventually the uniform committee decided to do without belts in the winter uniforms, but to issue a thin belt with a brass buckle, "of the type used by the American army," for the summer uniforms. ${ }^{55}$

The design of the IDF uniforms combined foreign influences and attempts to give uniforms a unique Israeli character. ${ }^{56}$ Adopted foreign items did not necessarily fit local conditions. The Medical Department opposed the Australian hat because it was heavy, and because it had to be tied under the chin, causing skin eczema. It also disqualified the stiff English cap as unsuitable for the local climate and dismissed the brimless soft cap, which eventually became the IDF general head-cover, claiming that it did not provide ample protection from the sun. In addition to modifying foreign items in order to adjust them to Israeli climatic conditions, the IDF wanted to distinguish its uniforms aesthetically. Thus, although the formal uniforms -issued only for soldiers and officers who represented the army abroad-were designed "after the American model," the Chief of Staff insisted that the shape of their caps should differ from American or British caps. ${ }^{57}$ Whereas modern battle dress uniforms put increasing store on practicality, price, and comfort, service and formal uniforms maintain the main lines of traditional uniforms. ${ }^{58}$ At the same time, uniforms should also distinguish different national armies. This dual purpose-of designing a "classic" uniform while also infusing it with unique national features-was clearly evident in the IDF during its first years of existence.

Traces of this search for specific characteristics within a worldwide military style were later apparent in the military salute as well. In early 1956 the IDF introduced a new military salute: the quickest and most direct raising of the right arm to the right side of the brow, with the tips of the finger touching the brow, the forearm faced diagonally downward, and the upper arm held straight and paralleling the front of the body. The IDF explained that this new salute replaced the previous one, which followed the American salute, in which the upper arm is held 45 degrees in front of the body. Some of the soldiers could not maintain 
their upright posture when saluting in the American way, and the new salute also solved the problem of the partial restriction of view on the right. The new salute did not include the long arc swinging of the arm that characterized the British salute, "and was found unsuitable for the Israeli style." ${ }^{9}$ By clarifying how it differed from foreign salutes, the IDF defined its new salute as particularly "Israeli."

Among its major roles, uniforms are meant to tell soldiers apart from civilians. But after the War of Independence, Israeli soldiers and civilians often wore very similar dress. In the summer of 1949, the IDF's bulletin Bamachaneh described a strange phenomenon to be noticed on the streets of Israeli towns: "Many of the people passing by are dressed in half-uniforms, [military] caps with no insignia, military shirts. On the other hand, it's hard to find two soldiers dressed in the very same uniform." The writer explained that "today's citizens are yesterday's soldiers," who had received khaki clothes when discharged from their army service; and besides "Khaki clothes have always been the national dress of Israelis"-evoking memories of the pre-state era, suiting the local climate, and fitting the conditions of the rationing regime. The IDF, continued the writer, cannot afford to order all its uniforms at once. Relying on chance bargains and gifts means that army uniforms remain at this stage diversified and non-uniform. ${ }^{60}$

Indeed, we recall that khaki had been a favorite color in the male version of the austere model of dress since the 1940s. Soldiers in the settlement units ("Nachal") spent some of their service in kibbutzim, and it was often hard to tell them apart from members of these kibbutzim in their working clothes. Ata was also a main manufacturer of the IDF uniforms, and, as noted before, its products for civilians shared a straight, military, cut. Military influence was also apparent in the popularity of the military-style short jacket (locally called "battledress") worn by many civilians, both men and women, in the 1950s. ${ }^{61}$

It is no wonder, therefore, that in late 1949 the uniform committee required that military uniforms be made "with a special khaki fabric, which will be strictly forbidden for civilians." It insisted on a special uniform shape, "because most civilians in our country tend to wear khaki during the larger part of the year, and it is often hard to differentiate a soldier from a civilian." There was also a need to distinguish the army from the police force, whose uniforms were blue, and the Air Force commander asked to make sure that the force's blue uniforms 
differ in shade from police uniforms. ${ }^{62}$

Uniforms unite all soldiers, but are also supposed to visually categorize soldiers according to their different forces, units, and ranks. The IDF ground forces wore khaki, while the Air Force's winter and service uniforms were dark blue, and the Navy's service uniforms were white. Another distinction was made by the military caps. Whereas all working hats were khaki, the service uniform caps differed in colors and shapes: white sailor caps for the Navy, blue caps for the Air Force, a stiff peaked cap for the Military Police, a black cap for the engineering and armored corps, red caps for the paratroops, and dark khaki caps for all the other ground corps. Some demands and requests regarding uniforms and insignia reveal a competition over prestige among different forces in the IDF, mainly between the Air Force and the parachute units. In addition, and despite the melting-pot effect of the military service, some visual differences abided. Thus one could tell a religious Yemenite soldier by his beard and long side-locks, whereas the master sergeant could usually be recognized by his huge moustache. There also remained clear differences between the regular army and the shabbier and less unified uniforms worn by soldiers in the reserves. ${ }^{63}$

Historically, uniforms helped to shape the bodies and the minds of soldiers and train them for battle: keeping one's uniforms clean and tidy demanded meticulous daily attention and care, and thus uniforms became a means of disciplining the individual soldier. ${ }^{64}$ Yet in the case of the IDF, the whole disciplining mission constantly met with a powerful contradiction: a local tradition of military informality. Casualness was deeply engrained in the Sabra sub-culture and was present within the Israeli military establishment through the heritage of the Palmach.

The Palmach (acronym for "plugot machatz," Hebrew for "strike platoons") was founded in 1941 as the elite fighting unit of the Haganah ("Defense"), the Yishuv's main and largest secret military organization. Its recruits-both men and women-went through extensive military training. Since it was an underground force and had to hide its training and activities from the British authorities, Palmach units were spread in kibbutzim, where its young recruits divided their time between farming and military activity. Its secrecy and lack of resources also affected the Palmach's military style. The motto "every squad commander is a general" reflected the initiative and resourcefulness expected of all soldiers, the close and informal relationship between commanders and 
their men, and the absence of formal ranks. The "Palmachniks" relied on mobility, flexible maneuvering, nocturnal guerilla tactics, and their intimate direct knowledge of the country's landscape. During the Palmach's years of existence and training as separate groups within the kibbutzim, Palmach men and women nurtured a strong camaraderie and created their own unique sub-culture, with extensive lore and a special sense of humor. Despite being a military organization, Palmachniks shunned formality and discipline, held neither ranks nor insignia, and practiced no military salutes or ceremonies. ${ }^{65}$

Palmach units bore the main share of fighting during the ArabJewish strife that began in late 1947, and later played a major role in the War of Independence. When the IDF was established in June 1948, the Palmach, like all other pre-state military organizations, was dismantled. Ben-Gurion insisted on the unity and the non-political character of the national Israeli army, but his decision regarding the dispersal of the Palmach was met with resentment and public debates. The IDF was to be a populist "army of the people," but the security needs of Israel during its first years, with constant Arab infiltrations through the volatile borders, required elite infantry units. And thus, only a few years after its dispersal, Palmach notions and style once again dominated the IDF. ${ }^{66}$

Yet even before the IDF adopted a formal policy of nurturing elite units, in which all soldiers were encouraged to show initiative and commanders and men held informal relationships, the spirit of the Palmach was never quite absent. Since its foundation, the Palmach was surrounded by a heroic aura and symbolized youth, pioneering, and committed love of the land. During the 1940s the Palmach became the body most associated with the Sabras and with the local "New Jew." During and after the war the Palmach was immortalized and celebrated in songs, drawings, and anecdotes. It was surrounded by nostalgic admiration and became an influential local myth. ${ }^{67}$ Among other things, the Palmach impact on Israeli culture and the IDF can be detected in the sphere of dress.

As a secret military organization, Palmach members naturally wore no uniforms. They "blended" into their kibbutzim's surroundings, wearing kibbutz working clothes and tembel hats of the kind described in the previous chapter. ${ }^{68}$ Palmachniks, both men and women, sometimes wore the Arab kafiya either as a head-cover or as a scarf, but by the 
outbreak of the war in 1948, the most typical hat covering the heads of many Palmachniks was a certain type of sock cap (beanie) with a large turn-up. Many Palmachniks wore their shirts deeply unbuttoned, uncovering a large part of their chest. Both male and female Palmachniks wore very short pants and leggings. ${ }^{69}$ Palmachniks took great pride in their informal and unkempt dress, which demonstrated their meaningful combat service in the front lines. During the war they scorned the grand, decorated, and meticulous uniforms worn by non-combat soldiers who served as clerks on the home-front. They could even distinguish members of the Haganah, fighters who did not belong to Palmach units: though the former also dressed in simple clothes, they were still tidier than the Palmachniks. ${ }^{70}$

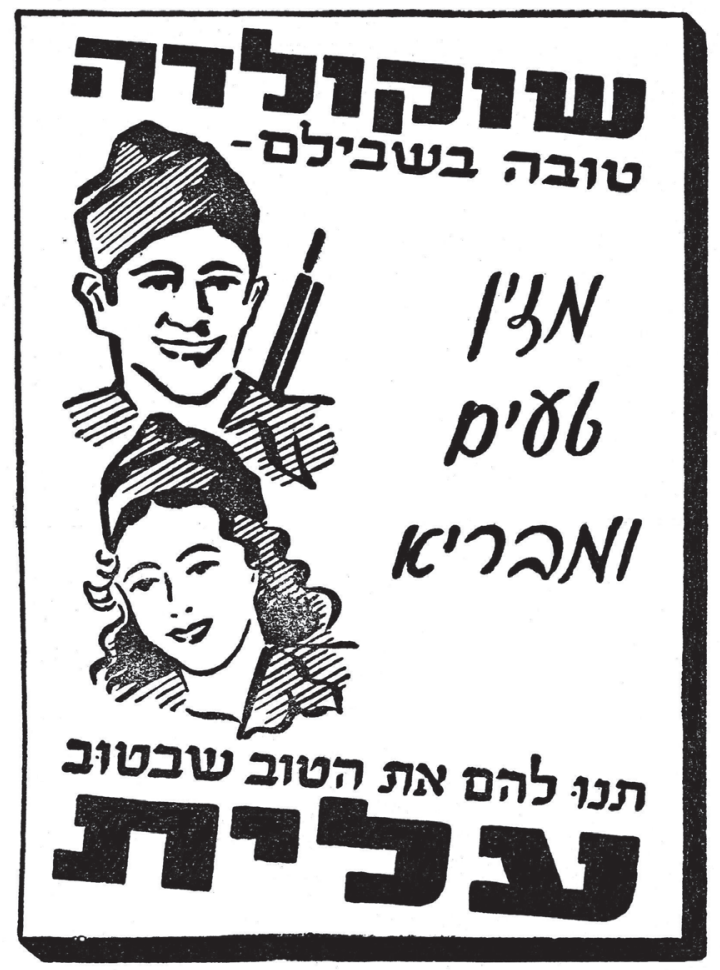

Figure 5.5: Figures of Palmach male and female soldiers in a chocolate ad: "Good chocolate for them-Give them the very best."

Beterem, January 1949. 
Although the Palmach was dismantled and uniforms and insignia were gradually introduced in the IDF alongside formal ranks, clearer command hierarchy, and military salutes, the Palmach spirit still lingered on in the IDF, especially in elite combat units. Many visual documents reveal an admiration of Palmach dress and disclose attempts to imitate it among IDF soldiers. ${ }^{71}$

Military pomp was therefore checked and minimized. The IDF viewed itself as an army devoid of redundant military ceremony. Many officers neither kept their uniforms tidy nor wore their rank's insignia. Soldiers in elite units were allowed, in practice, to disregard formal uniform codes, and their disheveled dress visibly manifested their higher military (and therefore social) status. Their informality reflected toughness, manliness, and no fear of physical discomfort. ${ }^{72}$ And vice versa: meticulous formal uniforms became a clear indication that the wearer was not a combat soldier, therefore placed in a lower military (and therefore social) status. In contrast to other armies, where higher status is reflected in a more spectacular uniform, in Israeli culture soldiers won more prestige if their uniforms were simpler, informal, and scruffy.

Formal attempts to discipline the appearance of Israeli soldiers were thus countered by the informal local military dress culture, which was intentionally and manifestly un-disciplined. Correspondence from the IDF archive and publications in the IDF bulletin Bamachaneh disclose how the army's discipline branch and its military police tried to put army soldiers, and especially disheveled officers, into sartorial order. "A neat appearance does not make an officer," reads a caption in Bamachaneh, "but officers are obliged to keep a neat appearance." ${ }^{73}$ The discipline branch fretted that the unkempt appearance of soldiers and officers, especially when they ventured out of the enclosed military camps and were seen in public, would disgrace the IDF among Israelis and, even more importantly, among foreign tourists and visitors. ${ }^{74}$

Nevertheless, alongside calls and slogans to keep up discipline and an orderly military appearance, Bamachaneh itself indirectly supported the disheveled dress of IDF soldiers, especially former-Palmachniks, and ridiculed attempts to discipline them. Many cartoons published in this army bulletin made fun of the master sergeant and the military policemen, presenting their antagonist, the undisciplined scruffy soldier, in an endearing light. Rather than presenting discipline as an integral 
and important part of the military regime, even Bamachaneh subverted its own formal slogans by depicting discipline as a distraction, which tampers with the real business of combat. ${ }^{75}$

One example among many is a cartoon by Fridl, a prominent female cartoonist. Published in Bamachaneh in September 1949, it shows a military policeman ordering a seated soldier "Pull down the sleeves!," and the latter replies, "Did you say anything, mate?" The cartoon required neither title nor further explanation, because its viewers, soon after the end of the war, could read and understand its meaning perfectly. The seated figure was a Palmachnik, a sturdy man who did the real fighting during the war and contributed to the victory. The wicked military officer, on the other hand, has nothing better to do than bother worthy soldiers about dress codes and discipline. The butt of the joke is the Palmachnik's total indifference to military discipline, as evident in his unkempt clothes, unruly hair, and leisured posture. Moreover, he feels neither respect nor fear toward the military policeman, and his familiar reply, added to his annoyed expression, indicates that he has no intention whatsoever of obeying the ludicrous order. The cartoon, published in the IDF bulletin, fully supports the Palmachnik, and portrays the military policeman (and by extension, military discipline in general) as a joke. ${ }^{76}$

Belonging to an "army of the people," IDF uniforms echoed the general Israeli culture, where simple and austere dress expressed the hegemonic national values. "In regular armies uniforms are so opulent, that they can be worn in the most snobbish evening balls," wrote a Bamachaneh reporter in 1949. "In our country, however, the soldier is camouflaged not only in the battle field, but also on the city's streets." The Israeli soldier, he wrote, must win respect and gratitude from the general public without wearing lavish uniforms, brilliant colors, and shining brass buttons. Even in drilling exercises and military parades he wears practical, simple uniforms: "This is the splendor and the pride of the Israeli soldier." ${ }^{\prime 7}$ From the outset, the IDF designed unostentatious uniforms, and due to the Palmach heritage and other local informal tendencies, these simple uniforms were worn without much ceremony or obedience. 


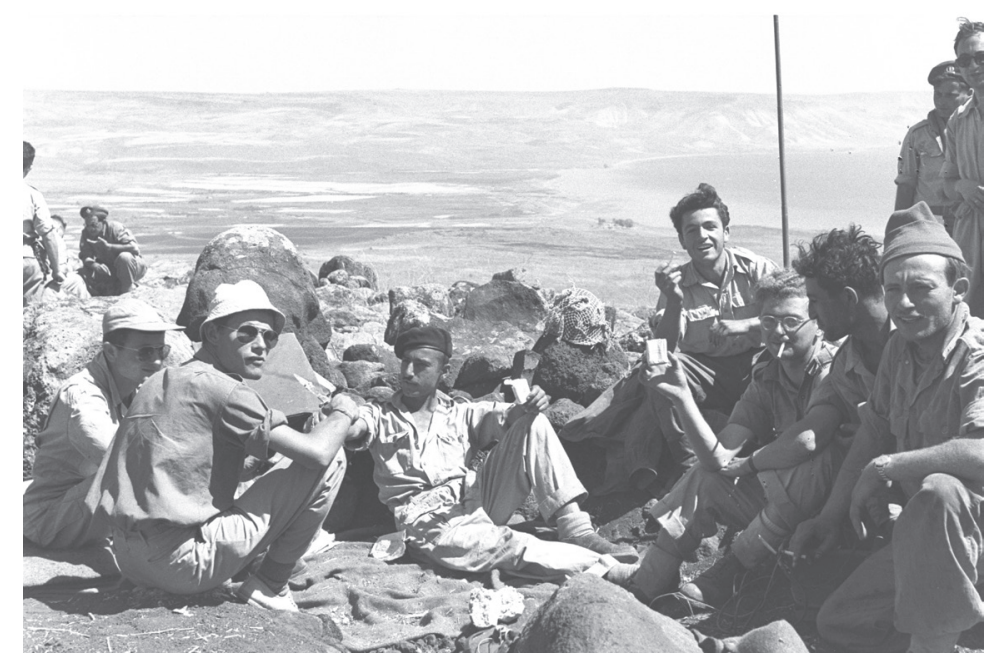

Figure 5.6: IDF soldiers after winning a Northern post from Syrian troops in May 1951. The combat soldiers are notably undisciplined in their dress, wearing a mishmash of clothes, including one Palmach sock cap (beanie) on the right.

Government Press Office, NPC, D383-123.

IDF uniforms maintained an aesthetic simplicity at home, but army officials who were visiting other countries for training or other formal purposes were supplied with special and more refined uniforms. Army commanders and military envoys claimed that having to appear in public without wearing "suitable" uniforms in countries such as the United States, Britain, and France, was embarrassing. ${ }^{78}$ Most insistent were military attachés, whose representative outfits included both military uniforms and full evening dress, and whose increasing demands often covered their assistants and wives in addition to themselves. ${ }^{79}$ Whereas the simplicity of IDF military uniforms was a source of local pride, Israelis away from home did not always maintain their modesty but rather tried to imitate their hosts' standards.

War is a male pursuit, and as George Mosse argues, it can be viewed as "an invitation to manliness." ${ }^{80}$ Military service encourages physical power and bravery, and legitimizes the use of violence-spheres that are traditionally attributed to men and to male culture. Uniforms too were molded from the outset to accentuate manliness. Wide shoulders (in relation to the hips) are considered a male characteristic, and most military uniforms visibly broaden the shoulders. ${ }^{81}$ There is ample evi- 
dence that military uniforms can arouse sexual interest, if not sexual attraction, although studies differ in their explanations of this phenomenon. Some attribute the erotic appeal of the uniform to its explicit visual manliness, while others connect it to its association with power and violence, with ideas of discipline and hierarchy that evoke fantasies of domination and submission. ${ }^{82}$

When women started serving in modern armies in the mid-twentieth century, they joined a masculine organization, where dress was intended to enhance notions associated with masculinity-physical strength, bravery, and the legitimate use of violence. The shape of the military uniform, designed to enhance the masculine form, inevitably disfigures or hides feminine contours. Similarly, the values represented by the uniform contradict prevailing ideals of femininity as soft, gentle, and homey. Women's uniforms were designed as a modified variation of men's uniforms, so they retained their basic masculine shape despite some "softening" changes. The aim was usually to give women's uniforms some hint of womanhood, but at the same time to conceal any explicit female sexuality. Military uniforms visually celebrate masculinity, but hush and restrain femininity. Since women are associated with fashion, women's service uniforms are modified more often according to changes in fashion, but whereas civilians enjoy the freedom of choice within fashion, women soldiers are extremely limited in their choice. ${ }^{83}$ Jennifer Craik mentions an inherent paradox in women's military uniforms: uniforms are meant to limit and discipline one's body and behavior, but since they are historically and strongly linked with masculinity, whenever a woman is seen in military uniform, it might evoke contrary associations of crossing borders and breaking boundaries. ${ }^{84}$

Women participated in the Yishuv's defense organizations since the beginning of the twentieth century. Thousands of women were active members in the Haganah, for instance, but their integration involved a constant struggle to reach positions of authority and attain new roles. Women's desire to play an active role in the defense of the community appears to have stemmed from patriotism rather than from feminist ideals. Rosenberg-Friedman writes that the myth of equality between the sexes in the Yishuv drew greatly upon the presence of women in the defense forces, especially women fighters in the War of Independence; but she notes that in fact women were mostly assigned to traditional roles, in the military as well as in society at large. ${ }^{85} \mathrm{~A}$ similar picture is 
drawn by Sasson-Levy, who writes that women's service was based on two models: the British army, where women served in non-combat jobs, thus freeing men for fighting; and the Haganah and Palmach, where women were integrated into all roles and units. Yet even the latter decided as early as 1941 to allocate special roles for women, and although they were trained as fighters and took active part in defending settlements, most of them served as medics and in communications. When the IDF was established in 1948 it opted for the British army model, and a separate women's corps was established. ${ }^{86}$

Like other modern armies, in the IDF women's uniforms were designed as a female variation of men's uniforms. In 1950, for example, men's uniforms included a hat, a combat coat, a shirt, a sleeveless pullover, combat pants, khaki leggings, a khaki tie (optional), and brown or black shoes. Women's uniforms included identical hats, shirts, pullovers, and ties, and differed only in their skirts, socks, and brown shoes. Most women soldiers had to wear service uniforms, and received a tailored coat and a wool skirt. Only those who served in specific locations and as drivers were allowed to wear battle dress uniforms that were identical to the men's. Curiously, photos reveal that although the loose working clothes hid the feminine figure, while service uniforms included a skirt and emphasized the waist with a belt, the latter did not create a more feminine look. The service uniforms, with their straight rigid lines, enhanced the shoulders but distorted the shape of feminine breasts and hips. ${ }^{87}$

Still, the acronym for "Women's Corps" in Hebrew is "chen," a word that also means grace and charm; and indeed women soldiers were expected to beautify the army. ${ }^{88}$ The IDF wanted to give women's uniforms "a nice look" and so the uniforms committee wrote in late 1949 to the fashion institute in Jerusalem, requesting designs for suitable women's uniforms: "The problem is to find uniforms that would be comfortable but also aesthetic and fit for the common figure among our girls in the ages of 18 to 20." 89 The following year the Head of the Women's Corps protested when it was decided, without consulting her, to stop supplying women soldiers with nylon stockings. In summer they can wear short socks, she claimed, but in winter stockings are a necessity for the nice appearance of the soldier, "who is also a woman." She claimed that dress discipline should not be imposed on women soldiers as harshly as on men soldiers. Her successor, the new Head of the Women's Corps, 
asked in late 1951 that the women officers' service uniforms should be made to their personal size, because

The uniforms are the dress worn by the officer most of the time (which is not an easy thing for a woman). And according to public opinion officers representing "the fair sex" should look nice.

A couple of years later she demanded that women soldiers be issued a different, feminine, and more fashionable hat, rather than dressing them in the same caps worn by men soldiers. ${ }^{90}$

The sphere of clothing thus supports the notion according to which a separate women's corps institutionalizes a more gendered army. Moreover, cultivating women soldiers' looks stood in reverse relations to their actual and practical military contribution. Hence in late 1955, when the IDF designed and supplied new uniforms, men's uniforms were determined by comfort and practicality, whereas women's uniforms "don't have to suit combat conditions," as most of them served as secretaries and other such roles. They could therefore wear in future dark khaki uniforms, a skirt, and "a jacket with a nice cut." 11

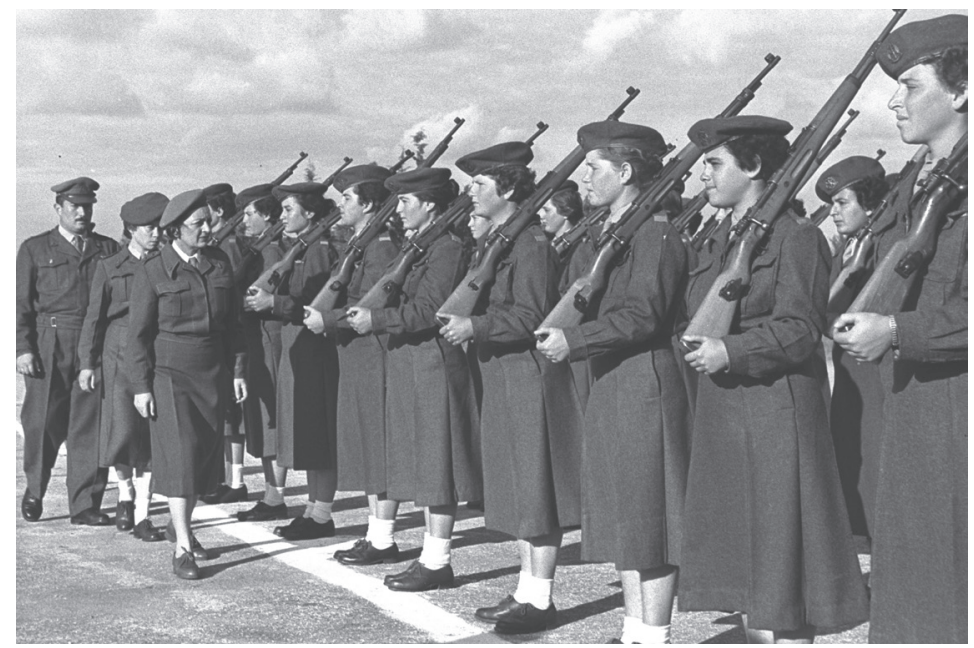

Figure 5.7: Inspection of women soldiers in an instructors' course, 1956. Government Press Office, NPC, D379-052. 
The woman soldier was sometimes depicted as a potential maid, whose true role was to iron the soldier's uniform or to sew his buttons for him. ${ }^{92}$ Historian Daniel Roche describes how the uniform, although the ultimate male dress, actually forced and taught soldiers to perform tasks that were traditionally associated with women, such as washing and darning. ${ }^{93}$ But then again, no women served in the French army in the eighteenth century, whereas women did serve in the IDF and could perform sartorial tasks for men.

In 1950 Bamachaneh published another cartoon by Fridl, in which a high ranking officer addresses his secretary: "And now, Ruchama, a private question that I have wanted to ask you for a long while ..." Ruchama, a conspicuously well-groomed soldier of a low rank, is looking at her commander expectantly. She is hoping for a romantic proposal, but the officer is holding his old socks behind his back, and is in fact about to ask Ruchama to darn them for him. Although Fridl drew the officer as a dubious "catch," a man with an unattractive figure and a simpleton's expression, the ultimate joke is at Ruchama's expense. She represents a type of woman soldier who serves in the army only in order to catch a husband, the higher his rank the better, but fails to realize her true goal in spite of her makeup and hairdo. Indirectly, and perhaps unintentionally, the cartoon also exposes the difficulties met by women IDF soldiers, who had to deal with boring and unappreciated jobs, lower ranks, dependence on male commanders, and confusing messages about their appearance and sexuality. ${ }^{94}$

As we observed in previous chapters, Israeli women were often required to avoid excessive vanity, which was regarded as contradicting important national priorities, but at the same time they were expected to boost national morale by nurturing the aesthetic fields and by pleasing the eye. ${ }^{95}$ During military service, these contradictory messages were particularly acute. On the one hand, women soldiers were rebuked for being too preoccupied with their looks; on the other hand, they were supposed to "decorate" the army and to provide a pretty sight for both soldiers and civilians. They were expected to maintain a feminine charm, but without looking overtly attractive or behaving flirtatiously. ${ }^{96}$

Maintaining a feminine look within the limitations of the military uniform was no easy task. Contemporaries noted that women basic trainees, once they were made to take off their civilian clothes and replace them with uniforms, went through a disappointing aesthetic 
transformation. This visual process of turning "from women to soldiers" was depicted in photographs and cartoons. Cartoons also pictured how women soldiers, who sometimes gained weight during their service, missed their former figures as well as their feminine, complimentary, civilian clothes. Although men soldiers too were sometimes illustrated in cartoons as longing for civilian clothing items, no cartoon ridiculed basic trainees transforming "from men to soldiers" by replacing civilian clothes with uniforms; on the contrary, military service, including military uniforms, only forged or enhanced men's masculinity. ${ }^{97}$ The War of Independence and the foundation of the IDF had turned the combat soldier, especially the paratrooper and the pilot, into a unifying national hero of mythic dimensions. The red cap of the paratrooper and his parachuting insignia became a well known status symbol in Israeli society. ${ }^{98}$

Military service, especially in combat units, was automatically connected to notions of heroism and manliness, and therefore the uniform became a "legitimate" field of male vanity, a sphere where grooming would not endanger one's sexual identity and tough image. ${ }^{99}$ Thus, alongside the heritage of intentional neglect, we can find some hints of men soldiers heeding their uniforms' looks, not just their efficiency and comfort. This tendency was particularly visible in the Air Force. Soldiers and officers in the Air Force voiced their opinions about their uniforms and insignia, complained about some of the designs allocated for the corps, and often added seams to the uniforms that they received from the quartermaster, "to make them look nicer." It is possible that the Air Force's insistence on a different and more elegant uniform was part of its competition with the paratroopers, who were celebrated for their Palmach-style shabbiness. Hence, when new summer uniforms were issued in 1956, the Air Force Commander complained that he was not consulted, and that the new uniforms would contribute nothing to the morale of his force. "The average soldier in the Air Force," he added indignantly, "does not aspire to imitate the paratroopers in his dress."100

Although uniforms are based on distinction-between the military and the civilian, between different units and ranks, between male and female soldiers - they also unify all soldiers under one national banner. ${ }^{101}$ The IDF was a main tool in the melting-pot project, and the image of the uniformed soldier became a cherished embodiment of the ideal New Israeli. ${ }^{102}$ 


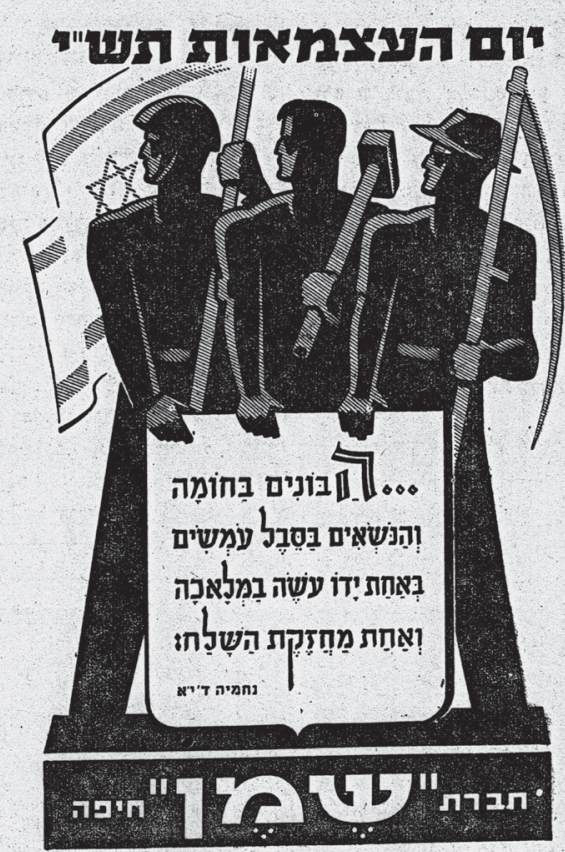

Figure 5.8: Dvar hashavu'a, April 20, 1950.

In 1950, the "Shemen" oil company published its greetings on Israel's second Independence Day. The inscribed quotation is from the Book of Nehemiah, chapter four, and reads,

They all built the wall and those who bore burdens loaded themselves; everyone with one of his hands worked in the work, and with the other held his weapon.

The building of the sovereign Israeli state is thus compared to the reconstruction of Jerusalem's walls in the days of the prophet Nehemiah, as both projects demand a combination of labor and defense. The young state and its main national tasks are incarnated in three masculine figures: alongside the farmer and the manual worker clutching their work tools, the image of the combat soldier is not holding an actual or symbolic weapon, as described in the Biblical text; instead he is waving the national flag of Israel. 


\section{NOTES}

1. Zmanim, May 9, 1955. Also see Dvar hashavu'a, November 23, 1950, January 4, 1951. Geva newsreels, 1954 - SA, VT GE 06.

2. Yom yom, April 25, 1949.

3. I would like to thank Ayala Raz for this information.

4. On uniforms of civilian pilots and air hostesses see Craik (2005), 110-113.

5. Haisha, 3, 1923. Hahed, 14/4-5, 1939. Raz (1996), 88-89, 162.

6. Davar, May 31, 1955. Compare with Finnane (2008), 207.

7. Dvar hapo'elet, May 1952.

8. Tarrant (1994), 52, 54; Mansel (2005), 37, 51-54, 114-115; Calefato (2004), 16; Eicher and Sumberg (1995), 300-301, 303. See also Trevor-Roper (2006), 20-25, 30-36; Finnane (2008), 212; Wilson (2003), 9; Stitziel (2005), 53.

9. For instance Sekatcheva (2004), 89, 91; Mansel (2005), 116-117; Assmann (2008), 360-361, 371; Allman (2004), 5.

10. Raz (1996), 88-89, 156-157. Photo from Dvar hashavu'a, October 25, 1951. 1950s WIZO blouses and shirts - SCA. And compare with Konenko (2007), 66; Guenther (2005), 109-118; Hason (1997), 19.

11. Ronen (1999); Roginsky (2007a), 47-52; Roginsky (2007b), 223-225, 232, 236; Roginsky (2009), 104-105. Letters from 1950 - ISA, 47/c-223/37.

12. Dvar hashavu'a, June 15, 1950. Photos from Kol yisrael, December 21, 1950; Dvar hashavu'a, August 30, 1951. Geva newsreels, 1951 - SA, VT GE 02.

13. Harrold (1986), 205; Roginsky (2007b), 239-244. Poster from 1953 - HMA: 21/2471-73808. Davar, September 16, 1955.

14. 1950s Hakuli Ltd. Israel metal plates - from the author's private collection. And compare with Konenenko (2007), 67, and Walton (2005), 7.

15. Roginsky (2007a), 42-44.

16. Cohen (2004), 110-113.

17. Compare with Tarlo (1996), 62, 319-323; Finnane (2008), 15, 17, 202-211, 220-225, 230, 249-254; Chen (2001).

18. Israeli Government, 1951, 83-90. Letters from 1949 and 1950 - ISA: 47/c223/43. Yediot aharonot, December 9, 1949. Ma'ariv, April 21, 1950. Dvar hapo'elet, May 1952. Omer, April 10, 1953. Davar, April 28, 1955, May 31, 1955. Geva newsreels, 1952, 1954, 1955 - SA: VT GE 01, VT GE 05, VT GE 06, VT GE 07. Also see Dowty (2001), 37.

19. Dvar hashavu'a, May 19, 1949. Herut, April 26, 1951. Rozin (2005), 186-188; Rozin (2002), 110. Compare with Finnane (2008), 209.

20. Letters from 1950 - ISA: 47/c-223/37. Geva newsreels, 1954 - SA: VT GE 07.

21. Polley (1998), 35. On the Soviet Union's case see Gradskova (2007), 120-123.

22. Helman (2008b), 108-113.

23. Helman (2008b), 109.

24. On the Israeli emblem see Mishori (2003), 138-164.

25. Meetings protocols, 1952 - ISA: C-4/5548. Photo from Sport la'am, August 3, 
1952. Geva newsreels, 1953, 1955 - SA: VT GE 04, VT GE 07.

26. Haisha bamedinah, February 1950. Also see Dvar hapo'elet, June 1949. Ha'olam hazeh, February 23, 1956.

27. Haisha bamedinah, October 1950.

28. Yediot aharonot: koteret, March 16, 1951. Ha'olam hazeh, March 11, 1954. Zmanim, June 10, 1955. Photos from 1956 by Fritz Cohen - NPC: D435-037, D541-079, D541-080.

29. Hayei sha'ah, November 26, 1953. Zmanim, June 26, 1955.

30. Zmanim, June 24, 1955. Haisha bamedinah, October 1950, August 1951. Hazofeh, December 24, 1954. Yossfer (1955). Davar, May 31, 1955.

31. Hentschell (2004), 50, 57; Gordenker (2001), 29; Stannek (2003), 339; Bowlt (1985), 203, 206, 209, 213, 217; Gradskova (2007), 118, 140; Finnane (2008), 209-210; Guenther (2005), 99-103, 200-201, 275-276; Paulicelli (2004), 142-143; Gori (2004), 169-175; Stitziel (2005), 54, 58, 63-65, 68; Stitziel (2008), 274.

32. Al hamishmar, August 24, 1950. Also see Dvar hashavu'a, December 14, 1950.

33. For instance see Shalom (1993); Katz and Paz (2004).

34. Haaretz, December 20, 1949.

35. Letter from 1950 - ISA: 47/c-222/31. Letter from 1950 - ISA: 47/c-223/38.

36. Raz (1996), 67-76, 125-163.

37. Ma'ariv, November 21, 1949.

38. Ma'ariv, March 31, 1949. Yediot aharonot, December 5, 1949. Haboker, July 6, 1952. Letter and protocol from 1956 - JCA: 2030/91/29, 1751/16.

39. Horowitz and Lissak (1990), 241, 250, 252, 256; Barak and Sheffer (2010), 33-34.

40. Drori (2000), 31-32; Levy et al. (2010), 147.

41. Helman (1999), 195-196.

42. Drori (1995), 609-610; Drori (2000), 32, 100-176.

43. Bar-On (1999), 65, 71, 83-84, 89-91.

44. Drori (2000), 100-123; Raz (1996), 159. Cover photo in Kol yisrael, December 14, 1950. Photo from 1949: NPC: D208-010. Illustrations in Ma'ariv, September 30, 1949; Bamachaneh la'oleh, January 10, 1950. Ads in Beterem, January 1949; Ma'ariv, December 3, 1950; Jerusalem Post, July 24, 1952. Independence Day greeting, Dvar hashavu'a, April 10, 1950.

45. IDF (1956), 18.

46. Dorot, October 20, 1949.

47. Geva newsreels, 1951, 1953, 1954 - SA: VT GE 02, VT GE 05, VT GE 06, VT GE 07. Photos in Bamachaneh, May 10, 1951, April 16, 1953, December 23, 1954, April 18, 1956; Ha'olam hazeh, May 13, 1954; Dvar hashavu'a, October 12, 1950. Radai (1956), 158-161. Letter from 1953 - IDFA: 641. On the Independence Day parade see Azaryahu (1998), 69-92. Also see Brownfield-Stein (2010), 311.

48. For example Kimmerling (1993); Lomsky-Feder and Ben-Ari (1999); Drori (1995); Sasson-Levy (2006); Cohen (2010), 243.

49. Roche (1994); Holman (1980), 9; McVeigh (2000), 39; Hunt (1996), 109. Also 
see Martin (2004), 228; Craik (2005), 119-120; Fussell (2002), 186; Wilson (2003), 35; Johnson and Lennon (1999), 7 n. 9.

50. Protocols and letters from 1948, 1949, 1950 - IDFA: 12, 7, 528, 529. Letter from 1950 - ISA: 47/c-15/224. Ma'ariv, May 18, 1949. And compare with the delayed production of Red Army uniforms in the Soviet Union - Bowlt (1985), 208.

51. Letters from 1950 - IDFA, 263.

52. Letters from 1950, 1951 - IDFA: 7, 263, 630, 635, 637.

53. Letters from 1950 - IDFA: 7, 263, 629.

54. Protocols from 1949 - IDFA: 529. Bamachaneh, September 27, 1951. Geva newsreels, 1951 - SA: VT GE 03.

55. Correspondence from 1950 - IDFA: 629, 630. On the history of khaki see Newark et al. (1996), 10-14; Alber (1999), 125-129; Craik (2005), 37-38.

56. Photo from 1953 - NPC: D374-070. Geva newsreels - SA: VT GE 02, VT GE 03, VT GE 05, VI GE 06. Bamachaneh, March 23, 1950, June 1, 1950, December 21, 1950, May 6, 1954, December 16, 1954. Photos from Dvar hashavu'a, June 29, 1950, July 20, 1950; Ashmoret, May 10, 1951. Protocol and letters from 1949 and 1950 - IDFA: 528, 429.

57. Letters from 1949, 1950, 1951 - IDFA: 12, 526, 528, 632, 635, 641.

58. Craik (2003), 142; Craik (2005), 49; Mendes and de la Haye (1999), 122; Hill (2004), 72.

59. Bamachaneh, January 18, 1956.

60. Bamachaneh, September 15, 1949.

61. Drori (2000), 65-99. Ma'ariv, August 10, 1949. Ad in Al hamishmar, January 14, 1949. Military uniforms are associated with heroism, and therefore civilian fashion seasonally adopts military elements, in particular during military conflicts, see Craik (2005), 48-49; National Maritime Museum (2007); Mansel (2005), 77-129; Moser (1998), 210; Mendes and de la Haye (1999), 122; Hill (2004), 72; Craik (2003), 142.

62. Protocol, letters, and military regulations from 1949, 1950 - IDFA: 7, 528, 630.

63. Letters and correspondence from 1949, 1950, 1951, 1952, 1956 - IDFA: 130, 424, 526, 529, 637, 640. Geva newsreels, 1952, 1954 - SA: VT GE 01, VT GE 06. Illustration in Schor (1956), 233. Dvar hashavu'a, July 15, 1949. Photos and illustrations, Bamachaneh, July 19, 1951, September 23, 1954, March 6, 1956.

64. Roche (1994), 228-229, 238-239; Wilson (2003), 35.

65. Gilad and Megged (1957). Also see Bar-Or (2010).

66. Horowitz (1993), 48-49.

67. Gelber (1996), 459; Almog (1997), 176-186; Keren (2004), 11-12, 22.

68. On the Palmach and the Kibbutzim see Spiegel (2010), 76-77.

69. Cover photos in Dvar hashavu'a, July 26, 1951, August 9, 1951. Ben-Amotz and Hefer (1956); Hefer (1956).

70. Bar-On (2006), 477, 482-483, 485, 488.

71. Cartoons in Bamachaneh, September 8, 1949, November 11, 1949. Geva newsreels, 1954 - SA: VT GE 05. Ashmoret, July 20, 1950. Bamachaneh, September 


\section{$14,1955$.}

72. Almog (1997), 338-339.

73. Bamachaneh, April 4, 1950.

74. Letters from 1951, 1952, 1953 - IDFA: 635, 637, 639.

75. Cartoons in Bamachaneh, June 16, 1949, September 22, 1949, November 16, 1950, January 1, 1952, July 6, 1955, Dvar hashavu'a, February 24, 1949. Bamachaneh, March 10, 1955.

76. Cartoon in Bamachaneh, September 22, 1949.

77. Bamachaneh, September 15, 1949. Also see Dvar hashavu'a, December 7, 1950. Ashmoret, May 24, 1951.

78. Letters from 1949, 1950, and 1951 - IDFA: 300, 364, 632, 633, 635, 636. Geva newsreels, 1952 - SA: VT GE 01. Cover photo of Bamachaneh, June 1, 1955.

79. Letters from 1952 and 1953 - IDFA: 101, 640, 641. Photos from Dvar hashavu'a, August 9, 1951, August 16, 1951.

80. Mosse (1985), 114-115. On the difference between men and women as a combination of nature and socialization see Bradley (2007), 17, 21, 24; Lips (2008), 83-85; Pinker (2004), 423-429; Gribbin and Gribbin (2000), 290-291, 308314; Workman and Reader (2004), 92-94.

81. Hillman (1999), 66-67; Fussell (2002), 11, 14; Craik (2005), 12.

82. Craik (2003), 139; Steele (1996), 180.

83. Eicher and Roach-Higgins (1993), 21; Young (1993), 267, 269, 273; Hillman (1999), 69-76, 78-79; Craik (2005), 12-13, 50, 80, 88, 90, 92-93.

84. Craik (2003), 142. Also see Johnson and Lennon (1999), 5.

85. Rosenberg-Friedman (2003), 122-123.

86. Sasson-Levy (2006), 41. And compare with Evans Clements (1985), 220, 227.

87. Letters from 1949 and 1950 - IDFA: 528, 632. Photos in Bamachaneh, June 22, 1950, April 8, 1954, April 18 ,1956; Dvar hashavu'a, March 8, 1951. Geva newsreels, 1956 - SA: VT GE 08.

88. For instance, Dvar hashavu'a, February 17, 1949, April 12, 1949. And see Brownfield-Stein (2010).

89. Letter from 1949 - IDFA: 529.

90. Letters from 1950, 1951, 1953 - IDFA: 630, 633, 637, 641.

91. Bamachaneh, October 19, 1955. On the struggle for allowing women soldiers to wear pants, see letters from 1951 and 1952 - IDFA: 638, 639.

92. Cartoon and cover photo in Bamachaneh, May 8, 1952, June 9, 1952.

93. Roche (1994), 233.

94. Cartoon in Bamachaneh, July 22, 1950.

95. For example Jerusalem Post, December 4, 1953. Yediot aharonot, July 6, 1956. Dagesh, July 1953. Herut, October 14, 1955.

96. Bamachaneh, June 22, 1950, September 28, 1955, April 4, 1956. Cartoons in Bamachaneh, July 17, 1949, November 3, 1949, May 4, 1950, December 7, 1950, July 24, 1954; Ashmoret, January 26, 1950. Ad in Jerusalem Post, July 24, 1952. Photo from 1955 - NPC: D369-055.

97. Dvar hashavu'a, March 23, 1950. Cartoons in Bamachaneh, February 9, 1950, 
December 7, 1950; Ashmoret, March 6, 1952. Yediot aharonot, March 18, 1949. Bamachaneh, April 3, 1952. And see Brownfield-Stein (2010), 315-316.

98. Sasson-Levy 2006, 13-14, 35; Almog (1997), 209-210; Raz (1996), 159. Photo from 1950 - NPC: D384-023. Ma'ariv, July 16, 1954. Cover photo in Bamachaneh, April 11, 1956.

99. See Bell (1976), 148; Black (2004), 36-37. On a similar "tolerance" of male vanity in the sphere of sports see Shannon (2006), 186-187.

100. Letters and correspondence from 1949, 1950, 1952, 1956 - IDFA: 7, 130, 424, $632,639$.

101. Roche (1994), 228-229, 238-239; Wilson (2003), 35.

102. Compare with Gradskova (2007), 119; Finnane (2008), 230-244; Paulicelli (2004), 76-77. 